\title{
Brachiopods from the Silberberg Formation (Late Eocene to Early Oligocene) of Atzendorf, Central Germany
}

\author{
Maria Aleksandra Bitner ${ }^{1}$ (D) Arnold Müller ${ }^{2}$
}

Received: 17 September 2014/ Accepted: 15 April 2015/Published online: 22 May 2015

(C) The Author(s) 2015. This article is published with open access at Springerlink.com

\begin{abstract}
Six brachiopod species, i.e., Discradisca sp., Cryptopora sp., Pliothyrina sp. cf. P. grandis (Blumenbach, 1803), Terebratulina tenuistriata (Leymerie, 1846), Rhynchonellopsis nysti (Bosquet, 1862), and Orthothyris pectinoides (von Koenen, 1894), have been identified in the Late Eocene to Early Oligocene Silberberg Formation of Atzendorf, Central Germany. The species $R$. nysti and $O$. pectinoides dominate the studied assemblage. Rhynchonellopsis is here transferred from the family Cancellothyrididae to Chlidonophoridae because it has a loop without united crural processes. Orthothyris pectinoides has a brachial skeleton of chlidonophorid type, but its transverse band is incomplete. In species composition, the assemblage from Atzendorf differs from other Paleogene and Neogene European assemblages by the absence of megathyridids and dominance of chlidonophorids, indicating a relatively deep environment.
\end{abstract}

Keywords Brachiopoda Rhynchonellopsis .

Orthothyris · Late Eocene · Early Oligocene · North Sea Basin · Germany

Maria Aleksandra Bitner

bitner@twarda.pan.pl

Arnold Müller

gmueller@rz.uni-leipzig.de

1 Institute of Paleobiology, Polish Academy of Sciences, ul. Twarda 51/55, 00-818 Warsaw, Poland

2 Institut für Geophysik und Geologie, Universität Leipzig, Talstraße 35, 04103 Leipzig, Germany
Kurzfassung Aus der obereozänen bis unteroligozänen Sibergerb-Formation von Atzendorf, Deutschland, konnten sechs Brachiopoden-Arten beschrieben werden: Discradisca sp., Cryptopora sp., Pliothyrina sp. cf. P. grandis (Blumenbach, 1803), Terebratulina tenuistriata (Leymerie, 1846), Rhynchonellopsis nysti (Bosquet, 1862), Orthothyris pectinoides (von Koenen, 1894). Die dominierenden Arten sind R. nysti und $O$. pectinoides. Aufgrund des Armgerüsts wird Rhynchonellopsis von der Familie Cancellothyrididae in die Familie Chlidonophoridae verschoben. Orthothyris pectinoides hat ein Brachialgerüst vom ChlidonophoridenTypus. In Hinblick auf die Artzusammensetzung unterscheidet sich die Vergesellschaftung von Atzendorf von anderen europäischen Vergesellschaftungen durch das Fehlen von Megathyrididen und eine Dominanz von Chlidonophoriden, was auf einen relativ tiefen Ablagerungsraum hinweist.

Schlüsselwörter Brachiopoda - Rhynchonellopsis . Orthothyris · Obereozän · Unteroligozän · Nordseebecken · Deutschland

\section{Introduction}

Oligocene brachiopods of Europe, unlike the Eocene and Miocene ones, are still poorly known. Their presence was mentioned in several older papers (e.g., Bosquet 1862; Sandberger 1862-1863; Vincent 1893, 1923; Sacco 1902; Fabiani 1913; Venzo 1941; Meznerics 1944; Mandruzzato 1970; Nebelsick et al. 2011), but in modern taxonomy they have been so far described only from the Lower Oligocene of Germany (Bitner and Kroh 2011), and from the Upper Oligocene of Austria (Radwańska and Radwański 1989) and France (Bitner et al. 2013). Recently, a 
rich assemblage of Oligocene brachiopods, comprising nine genera, was briefly reported from Hungary by Dulai (2010).

The aim of this paper is to describe a brachiopod fauna from the Late Eocene to Early Oligocene Silberberg Formation at Atzendorf, Central Germany. The investigated material, very rich in specimens, allowed examination of the hitherto unknown internal structures of Rhynchonellopsis nysti (Bosquet, 1862) and Orthothyris pectinoides (von Koenen, 1894), and thus to evaluate their systematic position. Some paleoecological and paleobiogeographical aspects are also discussed.

\section{Geological setting}

Atzendorf is situated in Central Germany, about $100 \mathrm{~km}$ northwest of Leipzig (Fig. 1), and the specimens were collected from a huge, abandoned gravel pit which was recently investigated in detail by Müller et al. (2014). Paleogeographically this locality is situated on the southeastern margin of the North Sea Basin. The

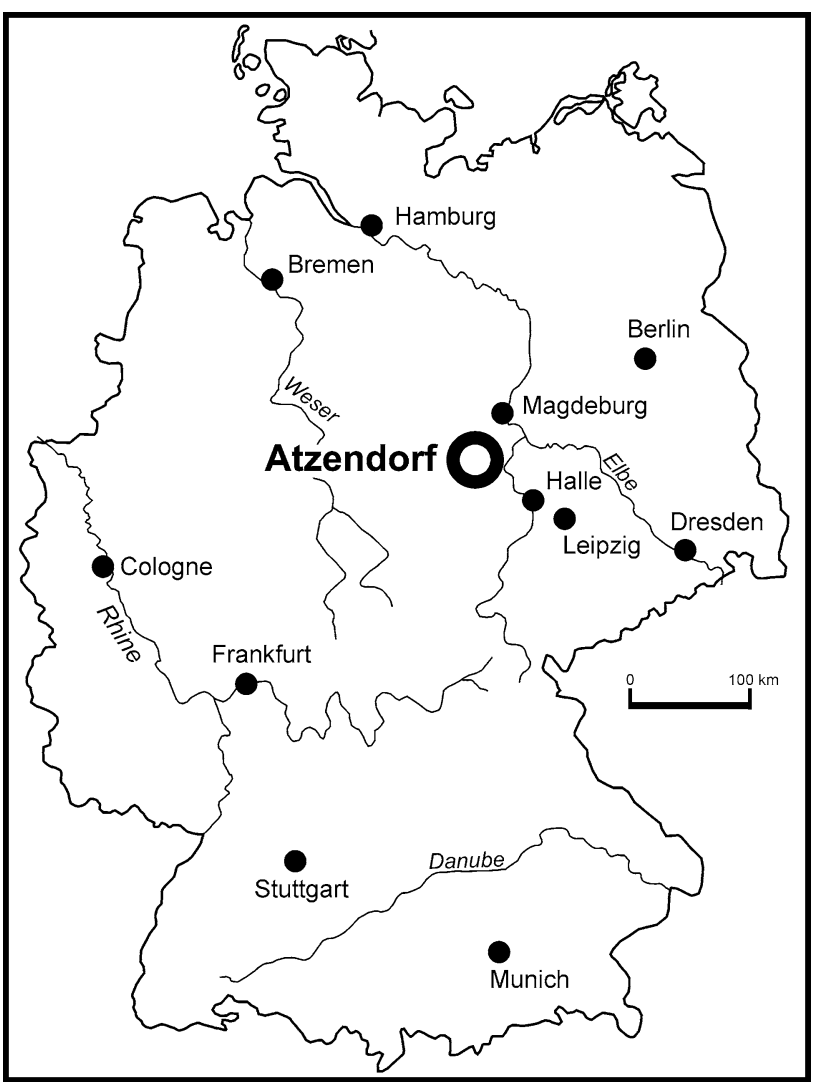

Fig. 1 Sketch map showing the locality Atzendorf at which the specimens were collected brachiopod-bearing deposits of the Silberberg Formation, which crop out in the Atzendorf gravel pit, lie unconformably on Lower Eocene sands and are overlain by thick Pleistocene gravels (Fig. 2). The Silberberg Formation is represented by clayey and silty deposits with a rich and diverse fauna of sponges, corals, bivalves, gastropods, brachiopods, bryozoans, echinoderms, and fishes, and is interpreted as representing a deep neritic environment (Müller et al. 2014). The formation comprises two parasequences, the lower Marbe and the upper Atzendorf Subformations. Although still under discussion, the age of this formation is considered to be uppermost Priabonian (Late Eocene) and lowermost Rupelian (Early Oligocene).

\section{Materials and methods}

All the investigated material was collected at Atzendorf, Central Germany (Fig. 1). The gravel pit was intensively sampled between 2008 and 2010 after exploitation of the Pleistocene gravel ended. The brachiopods come from bulk samples, each of $1.5 \mathrm{~kg}$ dry sediment, taken each $15 \mathrm{~cm}$ in the seven mining dug holes, and washed in the laboratory on a $0.4-\mathrm{mm}$ mesh. In addition, a few larger samples were taken at intervals of $90 \mathrm{~cm}$. For details of sampling see Müller et al. (2014).

Brachiopods were found in 97 of 120 samples, which contained from 1 to 652 specimens and a total of 3103 specimens. Although most specimens are excellently preserved, there are also many damaged and/or fragmented specimens. Biodiversity indices and rarefraction were calculated using the paleontological statistics software PAST (Hammer et al. 2001).

Specimens selected for scanning electron microscopy were mounted on stubs, coated with platinum, and examined using a Philips XL-20 microscope at the Institute of Paleobiology, Warszawa. The specimens described here are housed at the University of Leipzig, Germany under catalogue numbers AZ_0686-AZ_0738.

\section{Systematic part}

Phylum Brachiopoda Duméril, 1805

Subphylum Linguliformea Williams, Carlson, Brunton, Holmer, and Popov, 1996

Class Lingulata Gorjansky and Popov, 1985

Order Lingulida Waagen, 1885

Superfamily Discinoidea Gray, 1840 


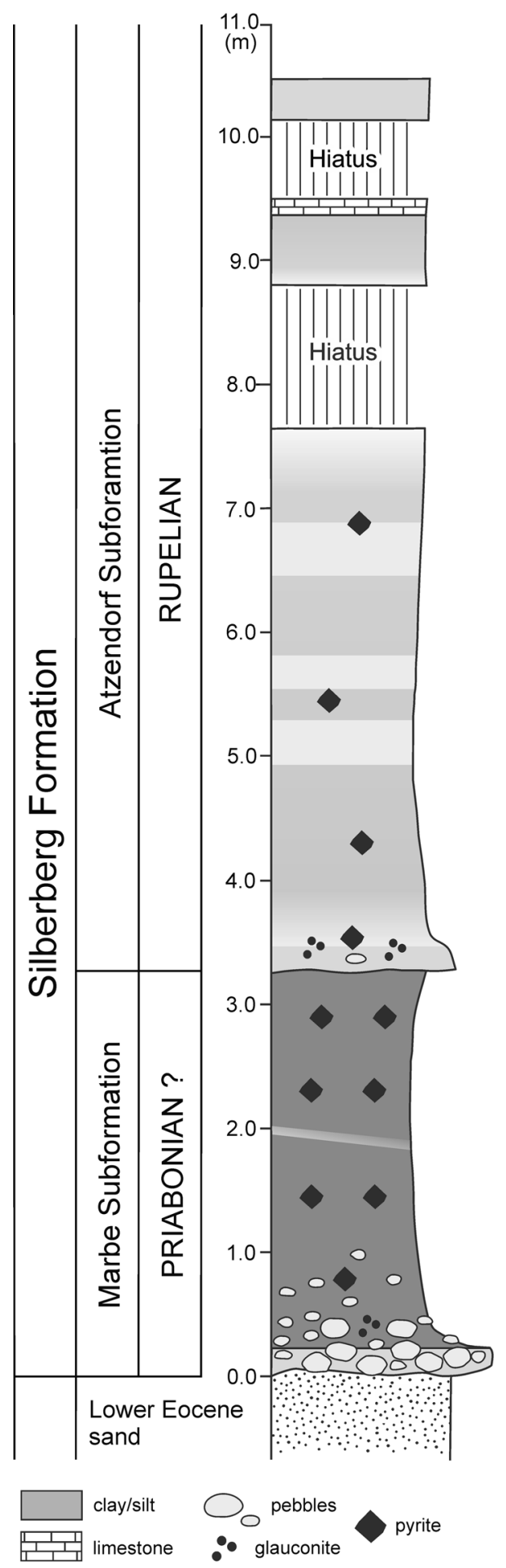

Fig. 2 Schematic section of the Atzendorf outcrop. Modified from Müller et al. (2014)

Family Discinidae Gray, 1840

Genus Discradisca Stenzel, 1964

Type species Orbicula antillarum d'Orbigny, 1845

\section{Discradisca sp.}

Figure $3 a-c$

Material Four, strongly broken, dorsal valves found in four samples.

Remarks The material, very limited and poorly preserved, resembles Discinisca, but ribbed ornamentation indicates its attribution to the related genus Discradisca (see discussion in Bitner and Cahuzac 2013, and Dulai 2013). The shell is thin and very small. Its postlarval (brephic) part (Fig. 3a) is smooth with numerous growth lines. The adult (neatic) shell (Fig. 3b) is covered with fine, tuberculate ribs which increase in number by intercalation. Apart from the ribs, the surface is also ornamented by numerous radial microlines (Fig. 3c). In the character of ribs and microornamentation, the studied specimens resemble Discradisca multiradiata (de Morgan, 1915) from the Miocene of France (Bitner and Cahuzac 2013; Dulai 2013); however, the present material prevents any conclusions.

Occurrence Silberberg Formation, Atzendorf, Germany. Several species of Discradisca have been reported from the Paleogene and Neogene deposits of Europe (see Bitner and Cahuzac 2013; Dulai 2013). Today, Discradisca lives in all oceans (Bitner et al. 2008; Bitner 2010, 2014).

Subphylum Rhynchonelliformea Williams, Carlson, Brunton, Holmer, and Popov, 1996

Class Rhynchonellata Williams, Carlson, Brunton, Holmer, and Popov, 1996

Order Rhynchonellida Kuhn, 1949

Superfamily Dimerelloidea Buckman, 1918

Family Cryptoporidae Muir-Wood, 1955

Genus Cryptopora Jeffreys, 1869

Type species Cryptopora gnomon Jeffreys, 1869

\section{Cryptopora sp.}

Figure 3d

Material One complete specimen of a young individual.

Dimensions Length $1.9 \mathrm{~mm}$, width $1.6 \mathrm{~mm}$ (AZ_0688).

Remarks The very limited material, i.e., one juvenile individual, prevents identification to species level, but it shows all characters typical of Cryptopora. The shell is very small, thin, and translucent, weakly biconvex with a smooth surface. The beak is high with a large, triangular, hypothyrid foramen flanked by very narrow, slightly raised deltidial plates. 


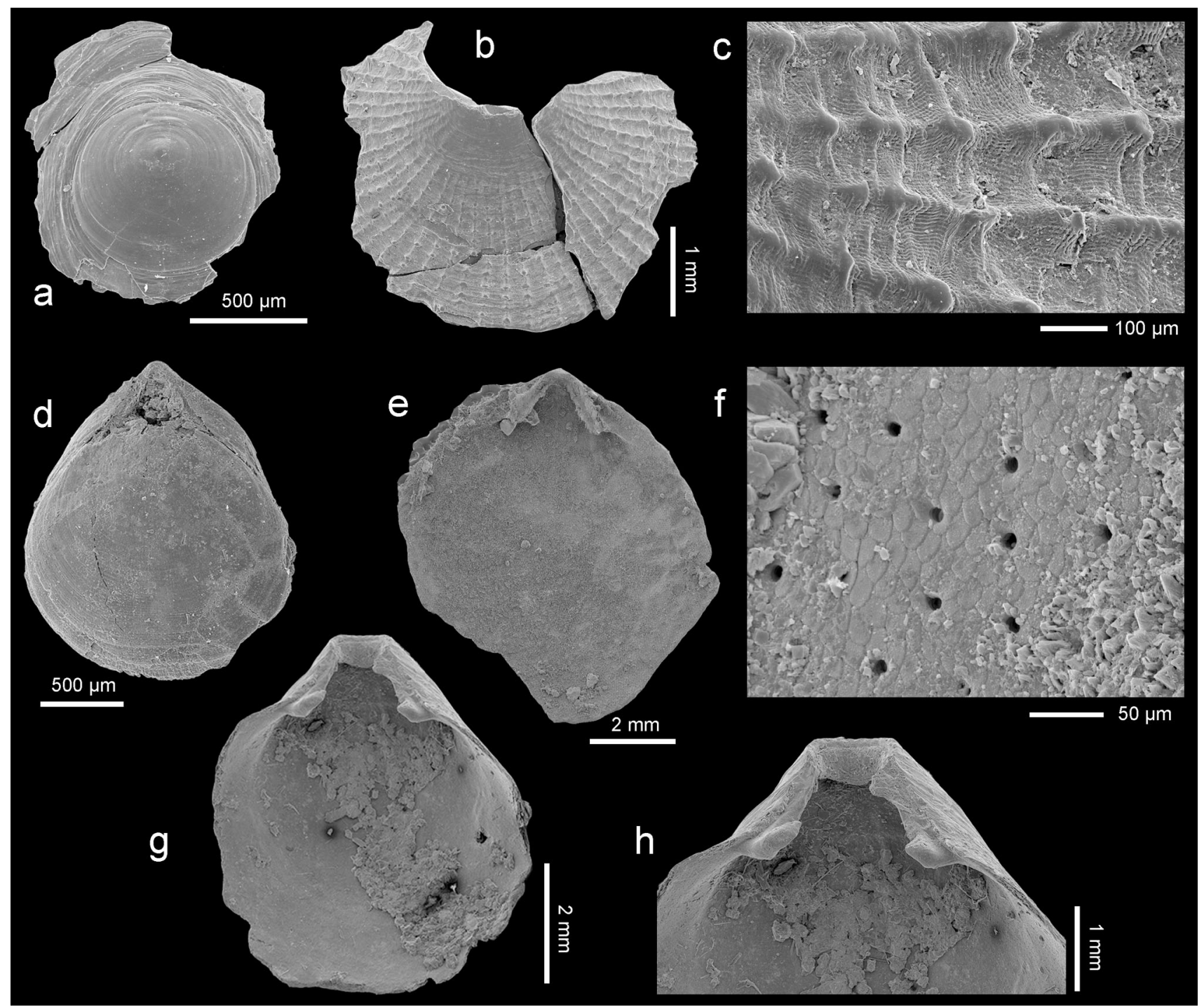

Fig. 3 Discradisca sp., dorsal valves, Atzendorf, Germany: a outer view of postlarval (brephic) shell, broken, no. AZ_0686; b, c outer view and enlargement (c) of the surface to show details of microornamentation, no. AZ_0687. d Cryptopora sp., Atzendorf, dorsal view of young, complete specimen, no. AZ_0688.

The specimen was found in the lower part of the section interpreted as uppermost Priabonian (Upper Eocene), thus this is the first record of Cryptopora from the Eocene of Europe. From the Oligocene of Europe, a doubtful Cryptopora is reported from Alsace; based on description and figures, Muir-Wood (1959) attributed the specimens described as Terebratula (Megerlea) haasi Andreae, 1884 from the Oligocene of Lobsann to the genus Cryptopora.

Occurrence Silberberg Formation, Atzendorf, Germany. The genus Cryptopora is known from the Danian to the Recent, but in the Eocene and Oligocene it is very rare (Andreae 1884; Toulmin 1940; Bitner and Cahuzac 2004). e-h Pliothyrina sp. cf. P. grandis (Blumenbach 1803), Atzendorf; $\mathbf{e}, \mathbf{f}$ inner view of dorsal valve and enlargement (f) to show mosaic of secondary fibers crossed by punctae, no. AZ_0689; $\mathbf{g}, \mathbf{h}$ inner view of ventral valve and enlargement (h) of umbonal part to show details of teeth, deltidial plates, and pedicle collar, no. AZ_0690. All SEM

Order Terebratulida Waagen, 1883

Superfamily Terebratuloidea Gray, 1840

Family Terebratulidae Gray, 1840

Genus Pliothyrina van Roy, 1980

Type species Terebratula sowerbyana Nyst, 1843

Pliothyrina sp. cf. P. grandis (Blumenbach, 1803)

Figure $3 \mathrm{e}-\mathrm{h}$

Material Two ventral valves and five dorsal valves, found in three samples; material partly damaged. 
Dimensions Length $6.2 \mathrm{~mm}$, width $5.1 \mathrm{~mm}$ (AZ_0690). Remarks The investigated specimens are most probably juvenile representatives of Pliothyrina grandis, the only short-looped terebratulide reported so far from the Oligocene of Northern Europe (Davidson 1874; Vincent 1886; von Koenen 1894; Cooper 1983; Müller 2011a; Diedrich 2012). The shell is elongate oval with smooth surface and rectimarginate anterior commissure. The foramen is subcircular, mesothyrid with disjunct deltidial plates. The ventral valve has short, excavate pedicle collar and small, hooked teeth (Fig. 3h). In the dorsal valve, the cardinal process is well developed, semielliptical. The inner socket ridges are long but low; dental sockets are shallow. The loop and crura are not preserved. The shell is composed of two layers, primary and fibrous secondary (Fig. 3f); twolayered shell is characteristic for all species of Pliothyrina (see van Roy 1980). Although usually the shell of articulate brachiopods is built of primary and secondary layers, in the majority of short-looped, smooth terebratulides it is composed of three layers (see MacKinnon and Williams 1974; Bitner 2007, 2014).

Occurrence Silberberg Formation, Atzendorf, Germany. The genus Pliothyrina is restricted to Northern Europe, being recorded from the Oligocene to Pliocene (Cooper 1983).
Superfamily Cancellothyridoidea Thomson, 1926

Family Cancellothyrididae Thomson, 1926

Subfamily Cancellothyridinae Thomson, 1926

Genus Terebratulina d'Orbigny, 1847

Type species Anomia retusa Linnaeus, 1758

\section{Terebratulina tenuistriata (Leymerie, 1846)}

Figure $4 \mathrm{a}-\mathrm{f}$

2000 Terebratulina tenuistriata (Leymerie)-Bitner, p. 118, figs. 2, 3, 4a-f, 5a-g (cum syn.).

2005 Terebratulina sp. cf. T. tenuistriata (Leymerie)Bitner and Dieni, p. 108, fig. 6a.

2008 Terebratulina tenuistriata (Leymerie)—Bitner and Dulai, pp. 33-35, fig. 4.1-8.

2009 Terebratulina tenuistriata (Leymerie)—Bitner and Boukhary, p. 396, fig. 3a-f.

2010 Terebratulina tenuistriata (Leymerie)—Dulai et al., p. 185 , pl. 3, figs. 1-11.

2011 Terebratulina tenuistriata (Leymerie)—Dulai, pp. 299-300, fig. 4.

2011 Terebratulina tenuistriata (Leymerie)—Bitner et al., pp. 122-124, fig. 3a-c.

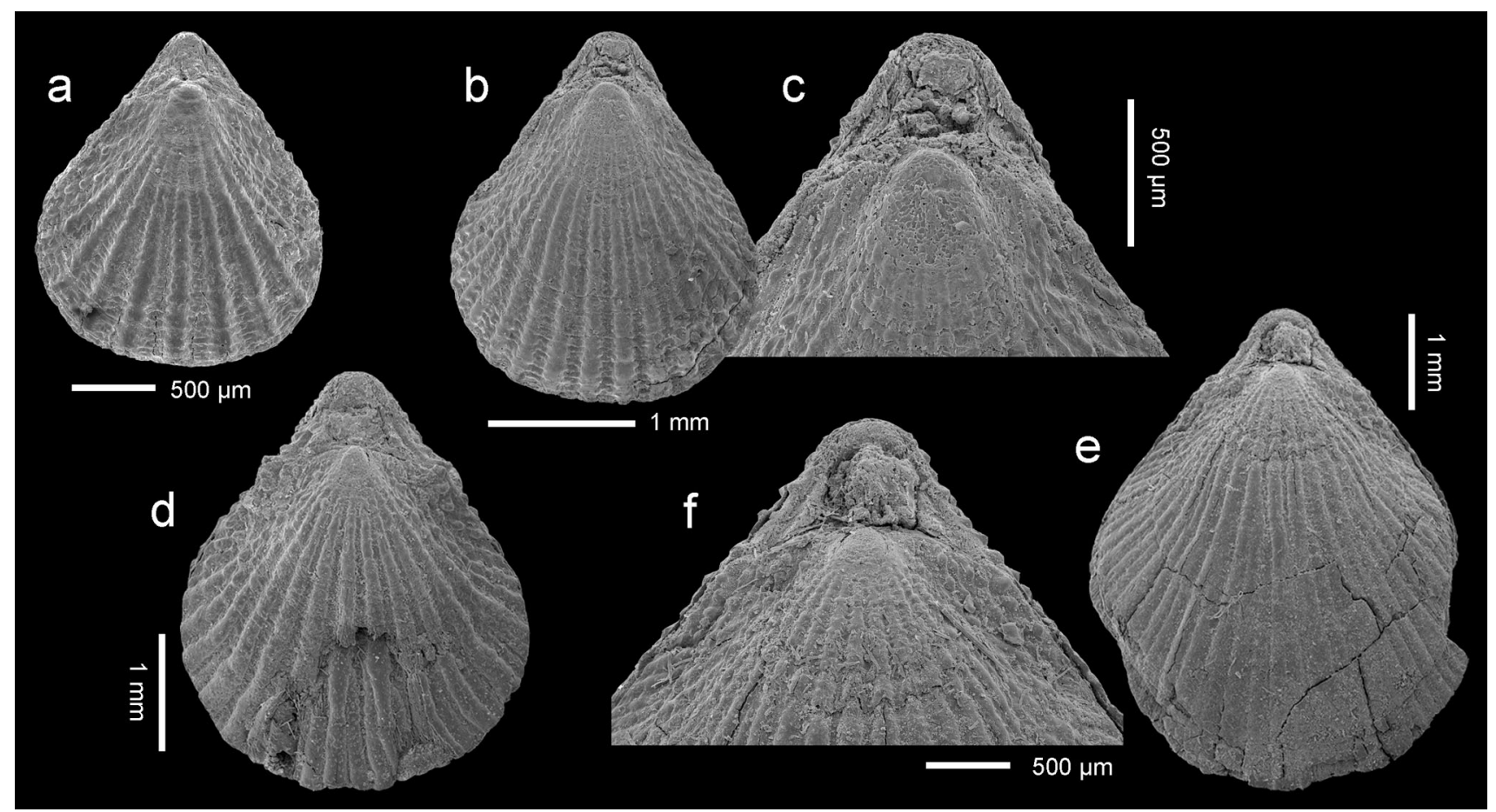

Fig. 4 Terebratulina tenuistriata (Leymerie, 1846), Atzendorf, Germany: a dorsal view of complete specimen, no. AZ_0691; b, $\mathbf{c}$ dorsal view and enlargement of umbonal part of another articulated specimen (c) to show details of the beak, no. AZ_0692; d dorsal view of complete specimen, no. AZ_0693; e, f dorsal view of another articulated specimen, and enlargement of umbonal part to show details of the beak, no. AZ_0694. All SEM 
2012 Terebratulina tenuistriata (Leymerie)-Bitner and Boukhary, fig. 2c-d.

Material 83 complete specimens, 21 ventral valves, and 6 dorsal valves, found in 33 samples.

Dimensions (in $\mathrm{mm}$ )

\begin{tabular}{llll}
\hline Specimen no. & Length & Width & Thickness \\
\hline AZ_0694 & 5.0 & 3.9 & 2.1 \\
AZ_0730 & 2.8 & 2.2 & 1.4 \\
AZ_0692 & 2.6 & 2.0 & 1.0 \\
AZ_0731 & 1.6 & 1.2 & 0.8 \\
\hline
\end{tabular}

Remarks The species Terebratulina tenuistriata is relatively common (more than 100 specimens) in the Atzendorf assemblage. Its shell is elongate oval, biconvex, ornamented by numerous fine ribs. Although young individuals of $T$. tenuistriata and Rhynchonellopsis nysti are very similar, adult shells of those species are easily distinguishable. The shell in T. tenuistriata is much thinner and nearly equally biconvex with a large pedicle opening, while $R$. nysti has a thick shell with a strongly convex dorsal valve. Additionally, both species differ internally in loop character; in adult shells of Terebratulina the crural processes unite to form a ring-like loop, whereas in Rhynchonellopsis the crural processes are not united.

Occurrence Silberberg Formation, Atzendorf, Germany. In the Eocene this species has a Tethyan distribution, being common throughout Europe from Great Britain to Ukraine, but also reported from Egypt and the United Arab Emirates (see Fig. 3 in Bitner and Boukhary 2012).

Family Chlidonophoridae Muir-Wood, 1959

Subfamily Chlidonophorinae Muir-Wood, 1959

Genus Rhynchonellopsis Vincent, 1893

Type species Terebratulina nysti Bosquet, 1862

\section{Rhynchonellopsis nysti (Bousquet, 1862)}

Figures 5, 6a-o, 7a-m

1862 Terebratulina nysti nov. spec.-Bosquet, pp. 5-6, fig. $6 a, b$.

1874 Terebratulina ornata Giebel-Davidson, p. 156, pl. 7 , fig. 16.

1886 Terebratulina ornata Gieb._-Vincent, p. 16.

1893 Terebratulina (Rhynchonellopsis) nysti BosquetVincent, pp. 50-52, pl. 3, figs. 12-14.

1894 Terebratulina nysti Bosquet-von Koenen, pp. 1352-1354, pl. 99, figs. 1-5, non fig. 6.

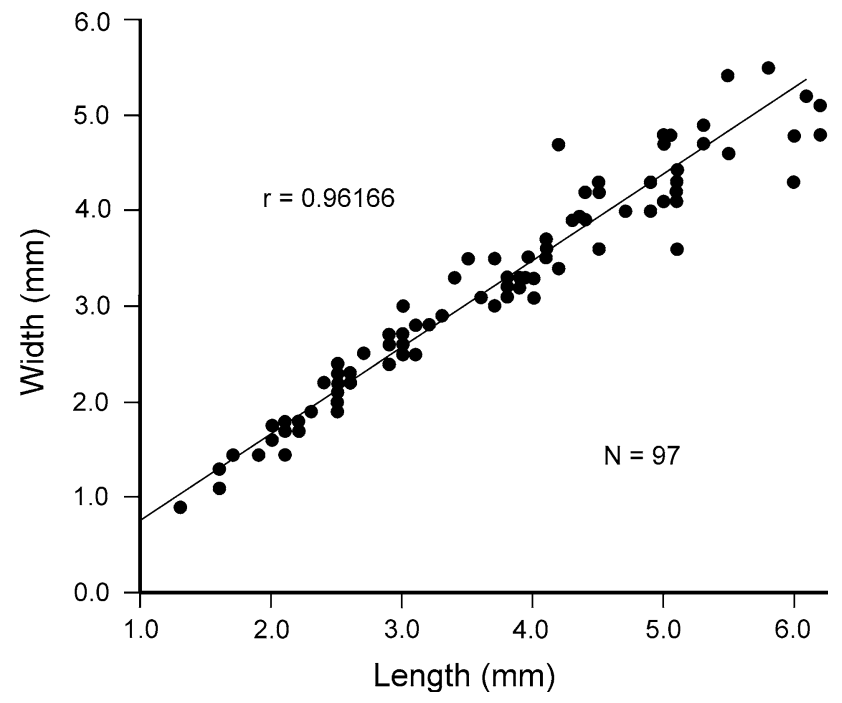

Fig. 5 Intraspecific variation in Rhynchonellopsis nysti (Bosquet, 1862). Scatter diagram plotting length/width. $N$ number of specimens

Non 1962 Terebratulina nysti Bousquet-Zelinskaya, p. 109, pl. 6, figs. 5, 6 .

Non 1975 Terebratulina nysti Bousquet-Zelinskaya, pp. 121-122, pl. 12, figs. 10-12.

2014 Rhynchonellopsis vincenti (Bosquet)-Müller et al., p. 92, pl. 1, fig. 11 .

Material 880 complete specimens, 558 ventral valves, and 420 dorsal valves, found in 85 samples.

Dimensions (in mm; see also Fig. 5)

\begin{tabular}{llll}
\hline Specimen no. & Length & Width & Thickness \\
\hline AZ_0703 & 6.2 & 4.8 & 2.8 \\
AZ_0732 & 5.3 & 4.7 & 2.5 \\
AZ_0699 & 4.4 & 4.1 & 2.1 \\
AZ_0702 & 3.9 & 3.2 & 2.0 \\
AZ_0733 & 2.6 & 2.2 & 1.2 \\
AZ_0734 & 2.1 & 1.8 & 0.9 \\
\hline
\end{tabular}

Description Shell small (maximum observed length $6.2 \mathrm{~mm}$ ), thick, biconvex in young to strongly dorsibiconvex in adults; ventral valve nearly flat (Fig. 6g, j). Shell outline variable from rounded to elongate oval with maximum width at or nearly mid-length (Fig. 6). Shell surface covered with numerous (up to 44) beaded tuberculate ribs which increase in number by bifurcation and intercalation; in young individuals ribs are single (Fig. 6a). Lateral commissure straight, anterior commissure rectimarginate to gently uniplicate (Fig. 6h, k). Hinge line very narrow, 


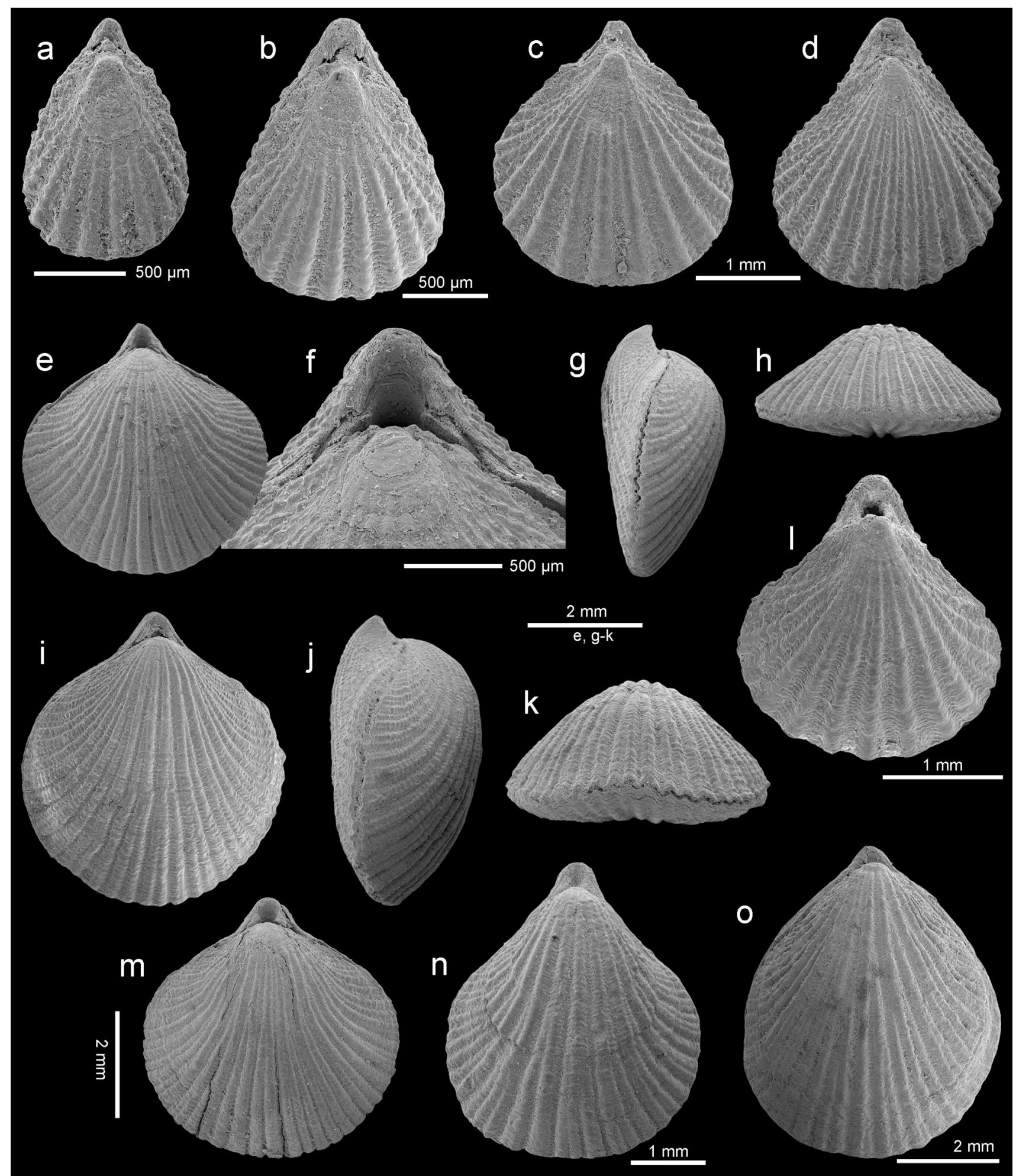

Fig. 6 Rhynchonellopsis nysti (Bosquet, 1862), Atzendorf, Germany: a, b dorsal views of complete young specimens, no. AZ_0695, AZ_0696; c, d dorsal views of complete specimens, no. AZ_0697,AZ_0698; e-h dorsal, lateral, and anterior views of complete specimen, and enlargement (f) of umbonal part to show details of the beak, no. AZ_0699; $\mathbf{i}-\mathbf{k}$ dorsal, lateral, and anterior views of complete specimen, no. AZ_0700; l-o dorsal views of complete specimens to show variability of outline, no. AZ_0701, AZ_0702, AZ_0703, AZ_0704. All SEM 


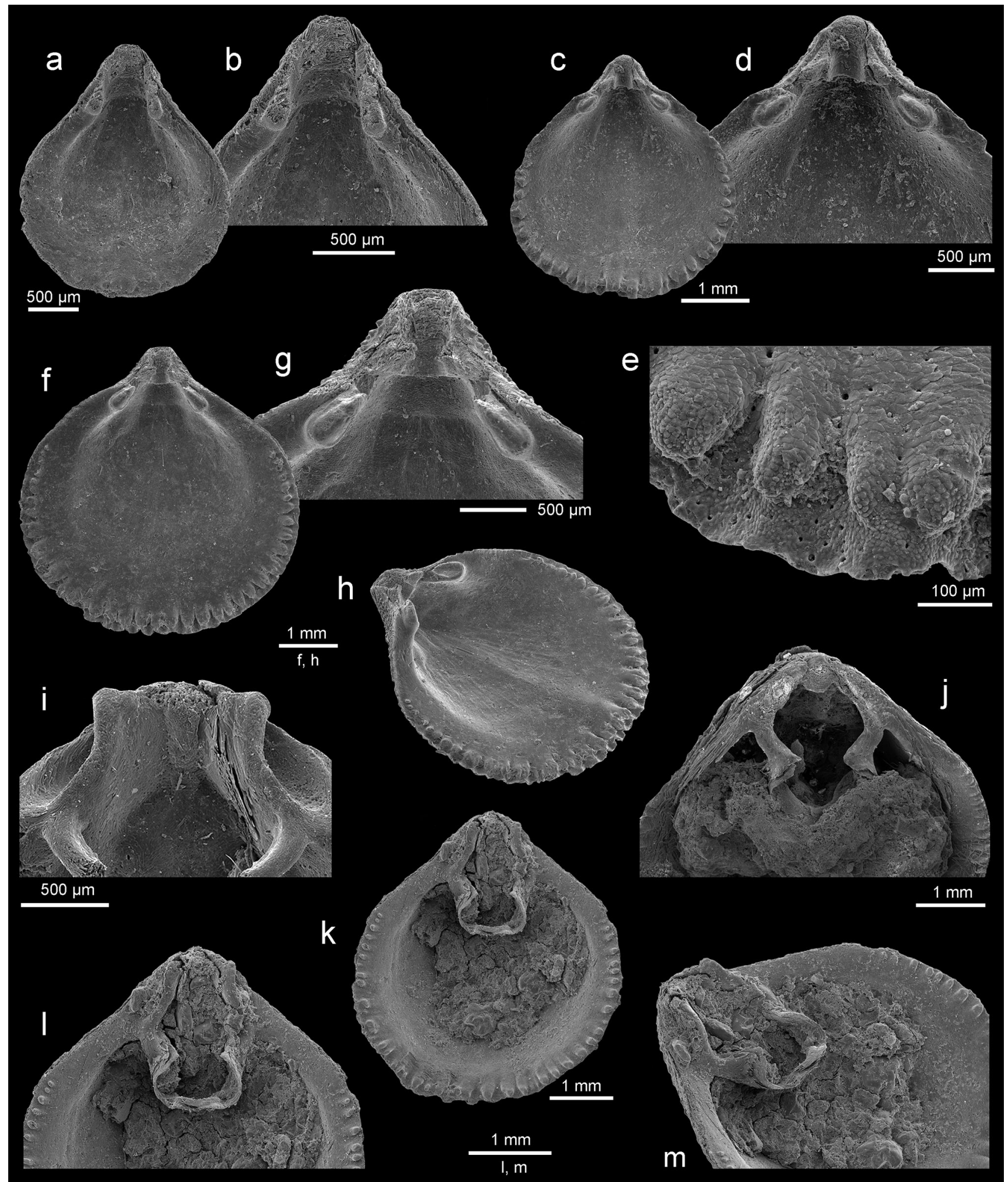

Fig. 7 Rhynchonellopsis nysti (Bosquet, 1862), Atzendorf, Germany: $\mathbf{a}, \mathbf{b}$ inner view of ventral valve of young individual and enlargement (b) of umbonal part, no. AZ_0705; c-e inner view of ventral valve and enlargement of umbonal part (d) and marginal tubercles (e), no. AZ_0706; $\mathbf{f}-\mathbf{h}$ inner view of ventral valve, enlargement of umbonal part $(\mathbf{g})$, oblique view (h) to show low median ridge, no. AZ_0707; i enlargement of umbonal part of dorsal interior to show prominent inner socket ridges and cardinal process, no. AZ_0710; $\mathbf{j}$ inner view of dorsal valve, visible loop of chlidonophorid type, no. AZ_0708; k$\mathbf{m}$ inner view of dorsal valve showing complete loop, and enlargement of umbonal part (I) and oblique view (m), no. AZ_0709. All SEM 
curved. Beak short, suberect; foramen small, oval, bordered by two small, triangular, disjunct deltidial plates.

Ventral valve interior with wide pedicle collar close to the valve floor (Fig. 7b, d, g). Teeth small, hooked, with swollen bases. Very low ridge present. Dorsal valve interior with prominent inner socket ridges projecting beyond hinge line, united with cardinal process and crural bases (Fig. 7i). Hinge plates absent. Crura short but massive and converging medially (Fig. 7i, j). Crural processes blunt and short, not united. Loop short with subparallel descending branches and a horizontal to slightly inclined posterodorsally transverse band (Fig. $7 \mathrm{j}-\mathrm{m}$ ). Inner shell margin of both valves strongly crenulated (Fig. 7c, e, f, h).

Remarks Rhynchonellopsis nysti is the commonest species (more than 1800 specimens) in the assemblage under study, and its internal structure has been investigated for the first time. Originally this species was described based on a single ventral valve from Belgium (wrongly interpreted as a dorsal one), by Bosquet (1862) as Terebratulina nysti. Later Vincent (1893) proposed for this species a subgenus Rhynchonellopsis, created by himself. Having only crura preserved, Vincent (1893) offered a loop reconstruction adding a ring that became the basis for attribution of $R$. nysti to the Cancellothyrididae. However, in the Cancellothyrididae the crural processes are united and, together with a transverse band, form a ring, whereas in Rhynchonellopsis the crural processes are seen to be not united, as in the Chlidonophoridae (Lee et al. 2006). Thus, this genus should be transferred into the latter family.

Rhynchonellopsis nysti was also reported from the Upper Eocene of Ukraine by Zelinskaya (1962, 1975); however, the description clearly negates the attribution of these specimens to $R$. nysti because the dorsal valve is flat whereas in $R$. nysti the dorsal valve is strongly convex. Also based on the illustrations it is not possible to confirm the attribution to $R$. nysti; the figures can represent any cancellothyridoid (see pl. 6, figs. 5, 6 in Zelinskaya 1962, and pl. 12, figs. 10-12 in Zelinskaya 1975).

Occurrence Silberberg Formation, Atzendorf, Germany. Lower Oligocene of Northern Europe (Belgium, The Netherlands, Germany) (Lee et al. 2006).

Subfamily Orthothyridinae Muir-Wood, 1965

Genus Orthothyris Cooper, 1955

Type species Orthothyris radiata Cooper, 1955

\section{Orthothyris pectinoides (von Koenen, 1894)}

Figures 8, 9a-p, 10a-k

1894 Terebratulina pectinoides von Koenen, pp. 1354-1355, pl. 99, figs. 8, 9.

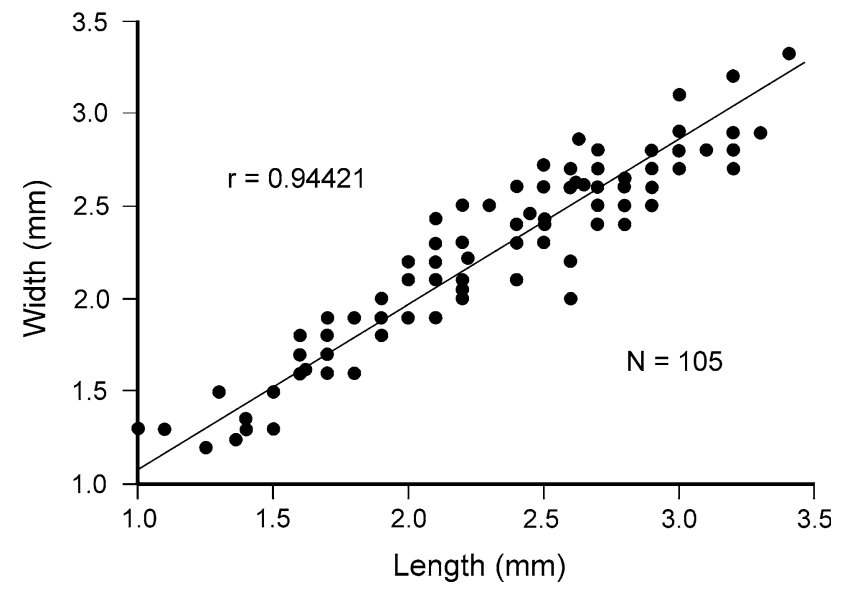

Fig. 8 Intraspecific variation in Orthothyris pectinoides (von Koenen, 1894). Scatter diagram plotting length/width. $N$ number of specimens

1975 Terebratulina pectinoides von Koenen-Zelinskaya, pp. 116-118, pl. 13, figs. 5-19.

2005 Orthothyris pectinoides (von Koenen)—Bitner and Dieni, pp. 108-109, figs. 5, 6b-n.

2008 Orthothyris pectinoides (von Koenen)—Bitner and Dulai, p. 35, figs. 4.9-16.

2010 Orthothyris pectinoides (von Koenen)—Dulai et al., p. 186, pl. 2, fig. 3 .

2010 Argyrotheca sabandensis? (Pajaud and Plaziat)Dulai et al., p. 186, pl. 2, figs. 5-11.

2011 Orthothyris pectinoides (von Koenen)—Dulai, pp. 303-304, fig. 7a-n.

2011b Orthothyris pectinoides (von Koenen)—Müller, fig. 17.

2014 Orthothyris pectinoides (von Koenen)—Müller et al., p. 92, pl. 1, fig. 10 .

Material 464 complete specimens, 199 ventral valves, and 460 dorsal valves, found in 45 samples.

Dimensions (in mm; see also Fig. 8)

\begin{tabular}{llll}
\hline Specimen no. & Length & Width & Thickness \\
\hline AZ_0719 & 3.2 & 2.9 & 1.8 \\
AZ_0735 & 3.1 & 2.8 & 1.8 \\
AZ_0718 & 2.6 & 2.9 & 1.5 \\
AZ_0736 & 2.1 & 2.2 & 1.2 \\
AZ_0737 & 1.7 & 1.9 & 0.8 \\
AZ_0738 & 1.4 & 1.3 & 0.7 \\
\hline
\end{tabular}

Description Shell small with maximum length $3.4 \mathrm{~mm}$, thick, variable in outline from elongate oval, subcircular, subpentagonal to transversely oval (Fig. 9). Shell unequally biconvex with ventral valve much more convex. 


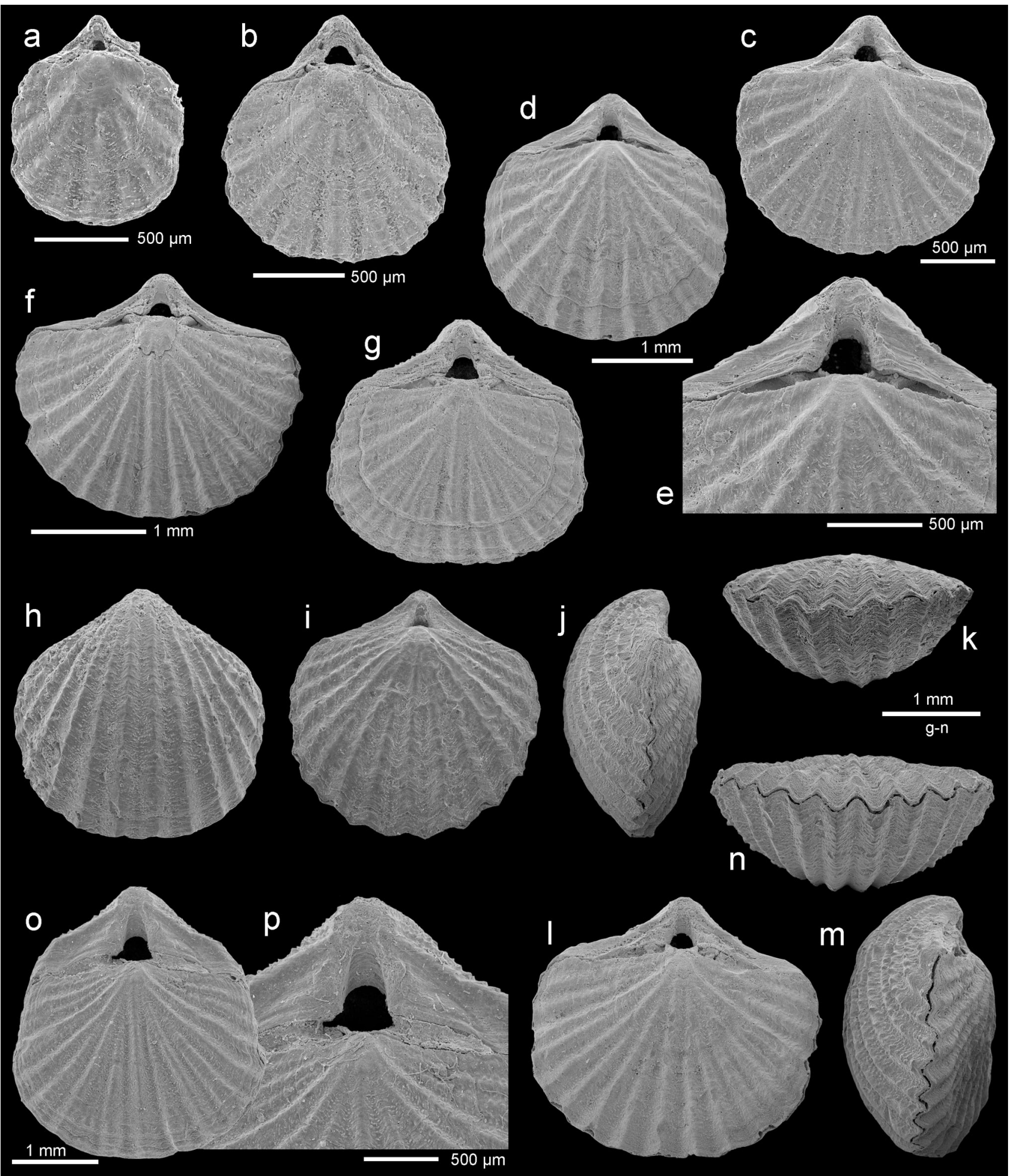

Fig. 9 Orthothyris pectinoides (von Koenen, 1894), Atzendorf, Germany: a-c dorsal views of complete immature specimens, no. AZ_0711, AZ_0712, AZ_0713; d, e dorsal view of complete specimen and enlargement (e) of umbonal part to show details of the beak, no. AZ_0714; $\mathbf{f}, \mathbf{g}$ dorsal views of complete specimens, no.
AZ 0715, AZ 0716; h-k ventral, dorsal, lateral, and anterior views of complete specimen, no. AZ_0717; l-n dorsal, lateral, and anterior views of complete specimen, no. AZ_0718; o, p dorsal view of complete specimen and enlargement (p) of umbonal part to show details of the beak, no. AZ_0719. All SEM 


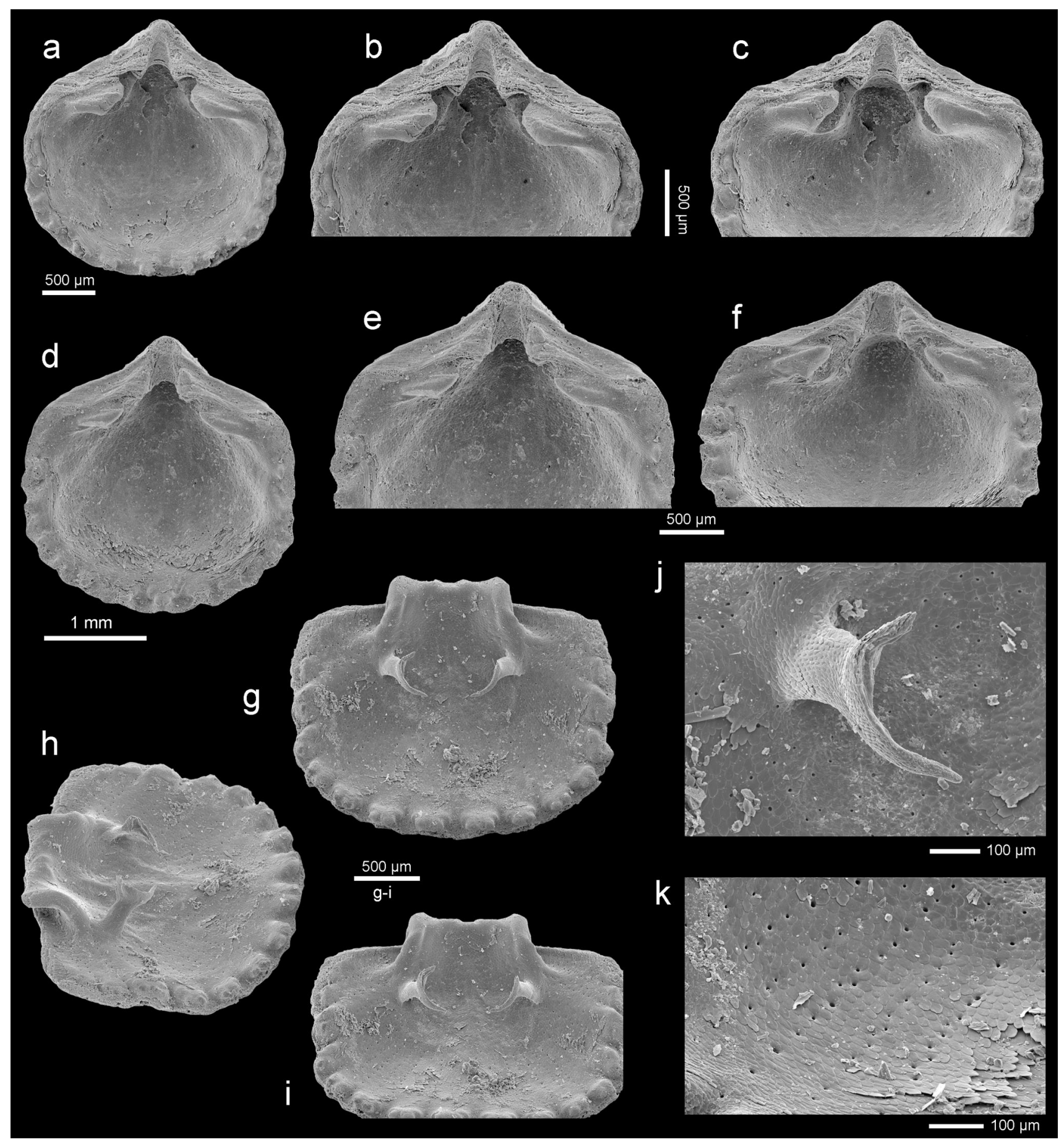

Fig. 10 Orthothyris pectinoides (von Koenen, 1894), Atzendorf, Germany: a-f inner views of ventral valves, and enlargement of posterior part $(\mathbf{b}, \mathbf{e})$ and tilted views $(\mathbf{c}, \mathbf{f})$ to show deep grooves to accommodate inner socket ridges, no. AZ_0720, AZ_0721; $\mathbf{g}-\mathbf{k}$ inner

Shell surface ornamented by distinct, beaded ribs, up to 24 in number. Lateral commissure straight, anterior commissure incipiently, broadly sulcate. Hinge line wide, straight to slightly curved. Beak erect with well-developed interarea and strong beak ridges. Foramen small, triangular, view of dorsal valve, oblique (h) and tilted (i) views, and enlargement of a crus with incomplete transverse band (j) and inner surface (k) to show punctae arranged in regular rows, no. AZ_0722. All SEM

hypothyrid; deltidial plates disjunct forming elevated ridges.

Interior of ventral valve with a well-developed pedicle collar. Teeth massive, beneath which deep grooves occur to accommodate inner socket ridges of dorsal valve 
(Fig. 10a-f). Dorsal valve interior with massive inner socket ridges erected beyond margin (Fig. 10g). Dental sockets deep. Posterior edge of socket ridges roughened, serving as a cardinal process. Crura short, stout, crural processes distinct. Loop short of chlidonophorid type but with an incomplete transverse band (Fig. 10g-j).

Inner commissure margin of both valves crenulated (Fig. 10d, g, h). Fibers of secondary layer readily visible on inner surface; punctae (Fig. 10k) arranged in rows associated with the rib region, a feature characteristic for Cancellothyridoidea.

Remarks Orthothyris pectinoides is one of the commonest species (more than 1000 specimens) in the investigated material. The specimens from Atzendorf correspond well to those hitherto described (e.g., Bitner and Dieni 2005; Bitner and Dulai 2008; Dulai 2011), being, however, larger.

The specimens from the Early Eocene of Austria described by Dulai et al. (2010) as Argyrotheca sabandensis? (Pajaud and Plaziat, 1972) clearly belong to O. pectinoides, fitting well within the variability range of this species. In addition, the specimens from Austria possess tuberculate ribs, a feature not observed in Argyrotheca.

Occurrence Silberberg Formation, Atzendorf, Germany. This species is widely distributed in the Eocene of Europe, being also reported from the United Arab Emirates (see Fig. 3 in Bitner and Boukhary 2012). In the Oligocene it is noted from Germany. Dulai (2010) mentioned Orthothyris? sp. from the Oligocene of Hungary.

\section{Discussion}

The brachiopod fauna collected from the Late Eocene to Early Oligocene deposits at Atzendorf, Central Germany (Fig. 1) is rich in individuals but of low diversity, containing six species belonging to six genera. Nevertheless, the rarefaction curve (Fig. 11), used to test the effect of sample size upon taxon counts, begins to flatten off, suggesting that further sampling would not substantially increase the number of taxa. Diversity indices show low diversity (Shannon index $=0.82$ ) and medium dominance (Simpson D index $=0.51$ ).

Lingulids and rhynchonellides are represented by one species each, Discradisca sp. and Cryptopora sp., respectively. The terebratulides have four representatives: shortlooped terebratuloid Pliothyrina sp. and three members of the superfamily Cancellothyridoidea, Terebratulina tenuistriata, Rhynchonellopsis nysti, and Orthothyris pectinoides. The two latter species dominate the assemblage, constituting $96 \%$ of the material. Rhynchonellopsis $n y s t i$ has long been considered as restricted to the Oligocene of the North Sea Basin, but the present finds extend its

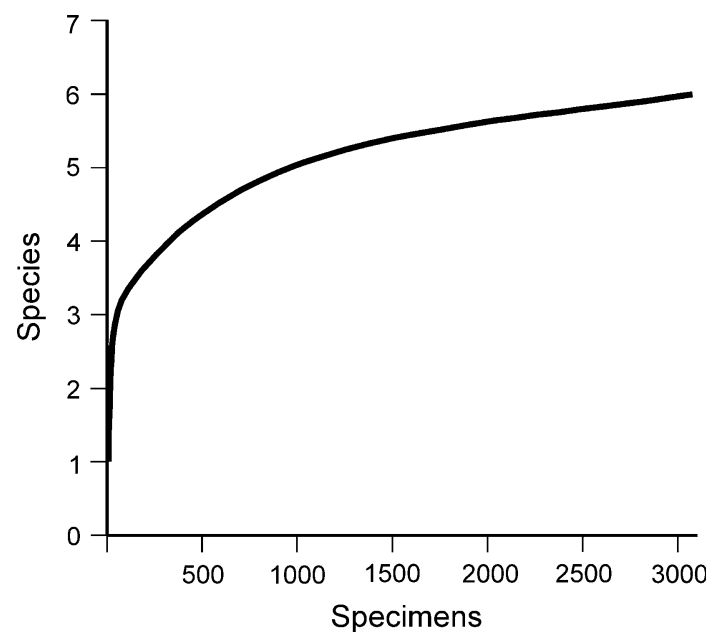

Fig. 11 Rarefaction curve for the brachiopod sample from Atzendorf

stratigraphical range to the Upper Eocene. However, the age of the deposits cropping out at Atzendorf is still under discussion (Müller et al. 2014). On the other hand, $T$. tenuistriata and $O$. pectinoides belong to the commonest species in the Eocene of Europe; from the Lower Oligocene they are reported from Northern Germany only.

The total absence of megathyridids (i.e., Megathiris, Argyrotheca, Joania), which are usually either common or dominant in other Paleogene and Neogene assemblages of Europe, makes the assemblage from Atzendorf clearly different. Today, megathyridids are commonest in shallowwater environments, preferring cryptic habitats such as overhangs, crevices, and caves (Logan 1975, 1979; Álvarez et al. 2005; Álvarez and Emig 2005), whereas the clayey deposits at Atzendorf may be interpreted as an originally soft sea bottom. The dominance of Chlidonophoridae, whose extant representatives are deep-water brachiopods (Logan 2007), indicates a deeper environment and supports previous interpretations of the Silberberg Formation (Müller 2011b; Müller et al. 2014).

All brachiopod species recognized in the Atzendorf assemblage have a functional pedicle opening, indicating that they lived attached to the hard substrate. The fauna, dominated by micromorphic species, is very similar to one described by Surlyk (1972) from the Upper Cretaceous white chalk facies. Surlyk (1972) suggested that small size may be considered as an adaptation to the availability of numerous but small hard substrates on a generally soft sea bottom. It is worth mentioning that the larger brachiopod, Pliothyrina sp., is rare and represented only by young individuals.

Traces of gastropod predation are extremely rare (Fig. 12); among 3103 specimens examined 26 (0.84\%) specimens were drilled. Such low predation intensity is a characteristic feature in Cenozoic brachiopod populations where molluscs, being more preferable food for gastropods, 


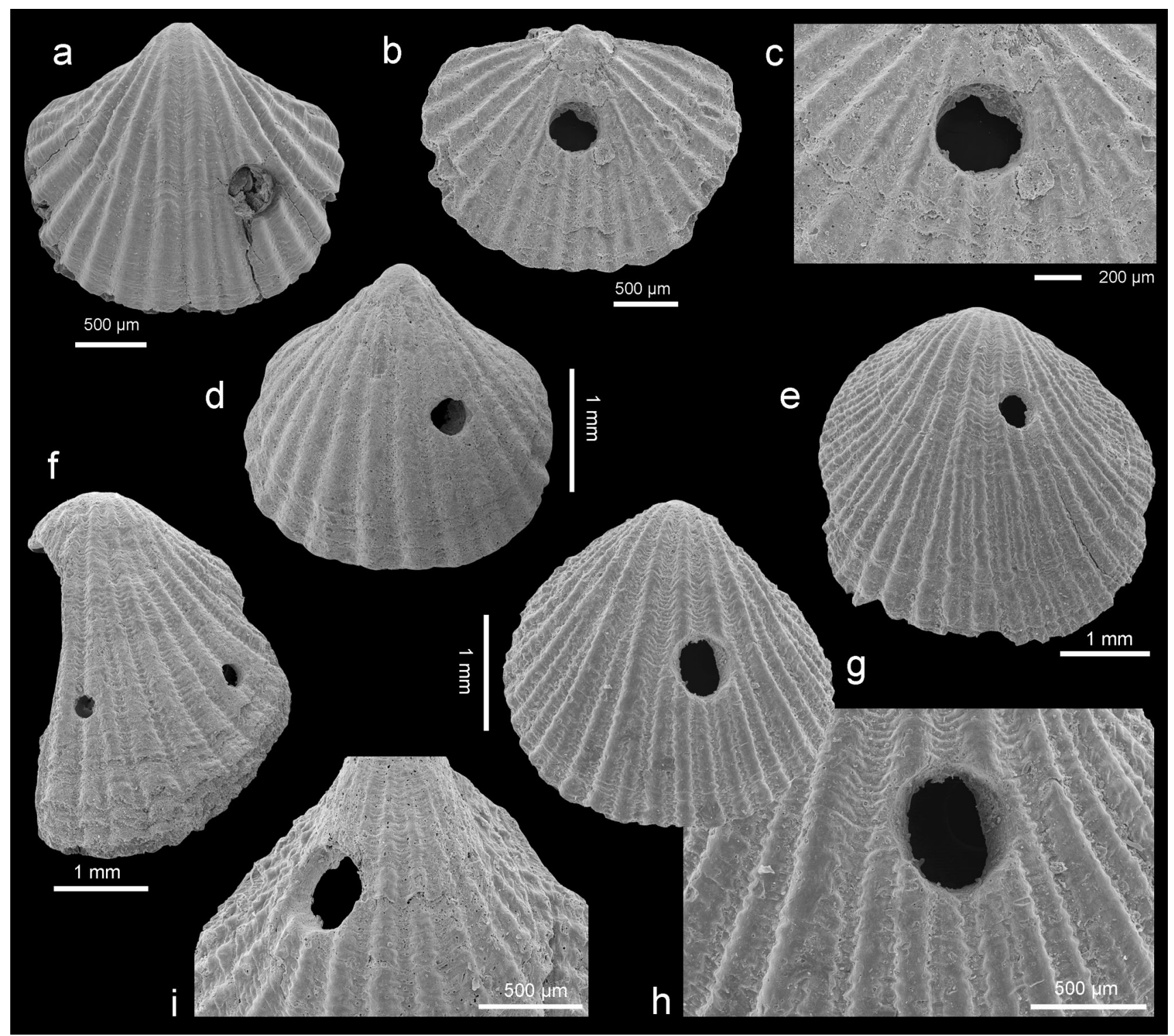

Fig. 12 Drilled brachiopods from Atzendorf, Germany. a-d Orthothyris pectinoides (von Koenen, 1894), a ventral valve, no. AZ_0723; b, c dorsal valve and a close-up image of drill hole (c), no. AZ_0724; d ventral valve, no. AZ_0725. e-i Rhynchonellopsis nysti
(Bosquet, 1862); e, f dorsal valves, no. AZ_0726, AZ_0727; g, $\mathbf{h}$ dorsal valve and a close-up image of drill hole (h), no. AZ_0728; i ventral valve, no. AZ_0729. All SEM

Table 1 Data on drill hole distribution in Rhynchonellopsis nysti and Orthothyris pectinoides from Atzendorf

\begin{tabular}{llllr}
\hline Species & Number undrilled & Number drilled (\%drilled) & Drilled on ventral & Drilled on dorsal \\
\hline Rhynchonellopsis nysti & 1837 & $21(1.1 \%)$ & 4 & 17 \\
Orthothyris pectinoides & 1118 & $5(0.4 \%)$ & 3 & 2 \\
\hline
\end{tabular}

are abundant (compare Taddei Ruggiero and Bitner 2008; Bitner and Cahuzac 2013; Bitner et al. 2013). Drill holes have been observed only on $R$. nysti and $O$. pectinoides (see Table 1), but any apparent taxonomic selectivity can be explained by the dominance of those two species. Drill holes were found on both valves of $R$. nysti but with a preference for the dorsal valve (see Table 1). The boreholes are small $(0.23-0.55 \mathrm{~mm})$, rounded in outline and cylindrical (Fig. 12), corresponding to those made by extant muricids. 


\section{Conclusions}

1. The Upper Eocene to Lower Oligocene Silberberg Formation deposits at Atzendorf, Central Germany yielded an abundant brachiopod fauna of low diversity. The assemblage consists of six species, Discradisca sp., Cryptopora sp., Pliothyrina sp. cf. P. grandis, Terebratulina tenuistriata, $R$. nysti, and O. pectinoides. The two latter species dominate.

2. The internal structures of $R$. nysti and $O$. pectinoides were investigated for the first time. Rhynchonellopsis nysti possesses a loop with disjunct crural processes and therefore has been transferred from the family Cancellothyrididae to the family Chlidonophoridae. Orthothyris pectinoides also has a loop of chlidonophorid type with an incomplete transverse band.

3. The dominance of chlidonophorid brachiopods and absence of megathyridids indicate a deeper-water environment.

4. Gastropod predation intensity on brachiopods is very low; drillings were observed on fewer than $1 \%$ of specimens.

Acknowledgments $\quad$ B. L. Cohen (University of Glasgow, Glasgow) is thanked for reading the manuscript, making useful comments, and improving the English. We wish to thank F. Álvarez (University of Oviedo, Oviedo) and A. Dulai (Hungarian Natural History Museum, Budapest) for their thorough reviews and supportive comments. Aleksandra Hołda-Michalska (Institute of Paleobiology, Warszawa) is thanked for help in the preparation of Fig. 2.

Open Access This article is distributed under the terms of the Creative Commons Attribution 4.0 International License (http://creativecommons.org/licenses/by/4.0/), which permits unrestricted use, distribution, and reproduction in any medium, provided you give appropriate credit to the original author(s) and the source, provide a link to the Creative Commons license, and indicate if changes were made.

\section{References}

Álvarez, F., and C.C. Emig. 2005. Brachiopoda. In: F. Alvarez, C.C. Emig, C. Roldan, and J.M. Vieitez, Lophophorata, Phoronida, Brachiopoda, in Fauna Ibérica, Vol. 27, eds A. Ramos et al., 57-276. Museo Nacional de Ciencias Naturales, Consejo Superior de Investigaciones Cientificas, 276. Madrid.

Álvarez, F., A. Martínez, L. Núñez, and J. Núñez. 2005. Sobre la presencia en Canarias de varias especies de braquiópodos (Brachiopoda: Rhynchonellata) en cuevas y cornisas submarinas. Vieraea 33: 261-279.

Andreae, A. 1884. Ein Beitrag zur Kenntnis des Elsässers Tertiärs. Abhandlungen zur geologischen Specialkarte Elsass von Lotharingen 2: 1-331.

Bitner, M.A. 2000. Lower Eocene (Middle Ilerdian) brachiopods from the Campo region, Central Pyrenees, north-eastern Spain. Revista Española de Paleontología 15: 117-128.

Bitner, M.A. 2007. Recent brachiopods from the Austral Islands, French Polynesia, South-Central Pacific. Zoosystema 29: 491-502.
Bitner, M.A. 2010. Biodiversity of shallow-water brachiopods from New Caledonia, SW Pacific, with description of a new species. Scientia Marina 74: 643-657.

Bitner, M.A. 2014. Living brachiopods from French Polynesia, Central Pacific, with descriptions of two new species. Pacific Science 68: 245-265.

Bitner, M.A., and M. Boukhary. 2009. First record of brachiopods from the Eocene of Egypt. Natura Croatica 18: 393-400.

Bitner, M.A., and M. Boukhary. 2012. First record of Eocene brachiopods from the United Arab Emirates, Arabian Gulf and their paleogeographical significance. Neues Jahrbuch für Geologie und Paläontologie Abhandlungen 265: 275-279.

Bitner, M.A., and B. Cahuzac. 2004. The genus Cryptopora (Brachiopoda) from the Miocene of France and its history and biogeography. Geobios 37: 1-12.

Bitner, M.A., and B. Cahuzac. 2013. New record of Discradisca (Brachiopoda: Discinidae) from the Early Miocene of the Aquitaine Basin, south-western France. Comptes Rendus Palevol 12: 23-29.

Bitner, M.A., and I. Dieni. 2005. Late Eocene brachiopods from the Euganean Hills (NE Italy). Eclogae Geologicae Helvetiae 98: 103-111.

Bitner, M.A., and A. Dulai. 2008. Eocene micromorphic brachiopods from north-western Hungary. Geologica Carpathica 59: 31-43.

Bitner, M.A., and A. Kroh. 2011. First record of the genus Bronnothyris (Brachiopoda: Megathyrididae) from the Oligocene of the Mainz Basin, Germany. Geologica Carpathica 62: 203-209.

Bitner, M.A., A. Dulai, and A. Galácz. 2011. Middle Eocene brachiopods from the Szőc Limestone Formation (Bakony Mountains, Hungary), with description of a new genus. Neues Jahrbuch für Geologie und Paläontologie Abhandlungen 259: 113-128.

Bitner, M.A., A. Logan, and E. Gischler. 2008. Recent brachiopods from the Persian Gulf and their biogeographical significance. Scientia Marina 72: 279-285.

Bitner, M.A., P. Lozouet, and B. Cahuzac. 2013. Upper Oligocene (Chattian) brachiopod fauna from the Aquitaine Basin, southwestern France and its paleoenvironmental implications. Geodiversitas 35: 579-606.

Blumenbach, F. 1803. Specimen archaeologiae telluris terrarumque imprimís hannoveranarum. Goettingae 1-28.

Bosquet, J. 1862. Notice sur deux nouveaux Brachiopodes, trouvés dans le terrain tertiaire oligocène du Limbourg néerlandais et du Limbourg belge. Comptes rendus de l'Académie Royale des Sciences 14: 345-350.

Buckman, S.S. 1918. The Brachiopoda of the Namyau beds, Northern Shan States, Burma. Memoirs of the Geological Survey of India. Palaeontologia Indica (new series) 3: 1-299.

Cooper, G.A. 1955. New Brachiopoda from Cuba. Journal of Paleontology 29: 64-70.

Cooper, G.A. 1983. The Terebratulacea (Brachiopoda), Triassic to Recent: a study of the brachidia (loops). Smithsonian Contributions to Paleobiology 50: 1-445.

Davidson, T. 1874. On the Tertiary Brachiopoda of Belgium. Geological Magazine 11: 150-159.

de Morgan, J. 1915. Note sur les Mollusques Brachiopodes des faluns de la Touraine. Bulletin de la Société Géologique de France 15: 260-273.

Diedrich, C.J. 2012. Palaeoecology, facies and stratigraphy of shallow marine macrofauna from the Upper Oligocene (Palaeogene) of the southern Pre-North Sea Basin of Astrup (NW Germany). Central European Journal of Geosciences 4: 163-187.

Dulai, A. 2010. Palaeogene brachiopods from the Late Eocene of Austria and the Oligocene of Hungary. In Program and Abstracts, 6th International Brachiopod Congress, February 
1-5, Melbourne, Australia; Geological Society of Australia, Abstracts 95:38-39.

Dulai, A. 2011. Late Eocene (Priabonian) micromorphic brachiopods from the Upper Austrian Molasse Zone. Memoirs of the Association of Australasian Palaeontologists 41: 295-313.

Dulai, A. 2013. Sporadic Miocene brachiopods in the Naturalis Biodiversity Center (Leiden, the Netherlands): Records from the Mediterranean, the North Sea, and the Atlantic Ocean. Fragmenta Palaeontologica Hungarica 30: 15-51.

Dulai, A., L. Hradecká, M. Konzalová, G. Less, L. Švábenická, and H. Lobitzer. 2010. An Early Eocene fauna and flora from "Rote Kirche" in Gschliefgraben near Gmunden, Upper Austria. Abhandlungen der Geologischen Bundesanstalt 65: 181-201.

Duméril, A.-M.C. 1805. Zoologie analytique, ou methode naturelle de classification des animaux, rendue plus facile à l'aide de tableaux synoptiques, 344. Paris: Allais.

Fabiani, R. 1913. I Brachiopodi terziari del Veneto, 3-42. Italy: Memorie dell'Istituto Geologico della R Università di Padova.

Gorjansky, W.J., and L.Y. Popov. 1985. Morphology, systematic position, and origin of the inarticulate brachiopods with carbonate shells. Paleontological Journal 3: 1-14. (in Russian).

Gray, J.E. 1840. Synopsis of the contents of the British Museum, 42nd ed. London: G. Woodfall.

Hammer, Ø., D.A.T. Harper, and P.D. Ryan. 2001. PAST: paleontological statistics software package for education and data analysis. Palaeontologia Electronica 4: 1-9.

Jeffreys, J.G. 1869. The deep-sea dredging expedition in H.M.S. "Porcupine". Nature 1: 135-136.

Kuhn, O. 1949. Lerhbuch der Paläozoologie, 326. Stuttgart: Schweizerbart.

Lee, D.E., T.N. Smirnova, and S. Dong-Li. 2006. Cancellothyroidea. In Treatise on Invertebrate Paleontology. Part H. Brachiopoda Revised. Vol 5, ed. R.L. Kaesler, 2145-2162. Boulder, Colorado and Lawrence, Kansas: Geological Society of America and University of Kansas.

Leymerie, M.A. 1846. Mémoire sur le terrain à Nummulites (Epicrétacé) des Corbières et de la Montagne Noire. Mémoires de la Société Géologique de France, deuxième série 8: 337-373.

Linnaeus, C. 1758. Systema Naturae, 823. Stockholm: L. Salrii.

Logan, A. 1975. Ecological observations on the Recent articulate brachiopod Argyrotheca bermudana Dall from the Bermuda Platform. Bulletin of Marine Science 25: 186-204.

Logan, A. 1979. The Recent Brachiopoda of the Mediterranean Sea. Bulletin de l'Institut Océanographique, Monaco 72: 1-112.

Logan, A. 2007. Geographic distribution of extant articulated brachiopods. In Treatise on Invertebrate Paleontology. Part H. Brachiopoda Revised. Volume 6, ed. P.A. Selden, 3082-3115. Boulder, Colorado and Lawrence, Kansas: Geological Society of America and University of Kansas.

MacKinnon, D.I., and A. Williams. 1974. Shell structure of terebratulid brachiopods. Palaeontology 17: 179-202.

Mandruzzato, F. 1970. Nota di aggiornamento sui macrofossili oligocenici di Laverda. Atti e Memorie dell'Accademia Patavina di Scienze 82: 167-270.

Meznerics, I. 1944. Die Brachiopoden des ungarischen Tertiärs. Annales historico-naturales Musei nationalis hungarici 36: 10-60.

Muir-Wood, H.M. 1955. A history of the classification of the phylum Brachiopoda. Bulletin of the British Museum (Natural History) 78: $1-124$.

Muir-Wood, H.M. 1959. Report on the Brachiopoda of the John Murray Expedition. Scientific Reports of the John Murray Expedition 1933-1934(10): 283-317.

Muir-Wood, H.M. 1965. Mesozoic and Cenozoic Terebratulidina. In Treatise on Invertebrate Paleontology. Part H. Brachiopoda, ed. R.C. Moore, 762-816. Lawrence, Kansas: Geological Society of America and University of Kansas.
Müller, A. 2011a. Der Steinbruch Mammendorf NW Magdeburgein Felslitoral der unteroligozänen Nordsee. Geologica Saxonica 57: $3-120$

Müller, A. 2011b. Paleogene of the Leipzig Embayment. Field Guide Excursion 1:1-18; GV and Sediment Meeting, Leipzig.

Müller, A., R.M. Leder, M. Henninger, and F. Bach. 2014. Die Silberberg-Formation im Profil von Atzendorf bei Stassfurt (Egelner Nordmulde, Sachsen-Anhalt, Deutschland). Geologisches Jahrbuch für Geowissenschaften 36: 73-133.

Nebelsick, J.H., D. Bassi, and M.W. Rasser. 2011. Cryptic relicts from the past: Palaeoecology and taphonomy of encrusting thecideid brachiopods in Paleogene carbonates. Annalen des Naturhistorischen Museums in Wien, Serie A 113: 525-542.

Nyst, P.-H. 1843. Description des coquilles et des polypiers fossiles des terrains tertiaires de la Belgique, 675. Bruxelles: M. Hayez.

Orbigny, A. d' 1845. Mollusques. In Historique physique, politique et naturelle de l'île de Cuba, vol. 2. ed. M. Ramon de la Sarga, 1-376. Paris: A. Bertrand.

Orbigny, A. d' 1847. Considérations zoologiques et géologiques sur les brachiopodes ou palliobranches. Comptes Rendus hebdomadaires des Séances de l'Académie des Sciences 25: 266-269.

Pajaud, D. and J.C. Plaziat. 1972. Brachiopodes thanétiens du synclinal sud-cantabrique au S.-E. de Victoria (Pays Basque espagnol). Étude systématique et interprétation paléoécologique. Bulletin de la Société d'Histoire Naturelle de Toulouse 108:446-473.

Radwańska, U., and A. Radwański. 1989. A new species of inarticulate brachiopods, Discinisca steiningeri sp. nov., from the Late Oligocene (Egerian) of Plesching near Linz, Austria. Annalen des Naturhistorischen Museums in Wien 90A: 67-82.

Sacco, F. 1902. I Brachiopodi dei terreni terziarii del Piemonte e della Liguria, 50. Torino: Clausen.

Sandberger, C.L.F. 1862-1863. Die Conchylien des Mainzer Tertiärbeckens. Parts 7 and 8, 233-468. Wiesbaden: C.W. Kreidel's Verlag.

Stenzel, H.B. 1964. Stratigraphic and paleoecologic significance of a new Danian brachiopod species from Texas. Geologische Rundschau 54: 619-631.

Surlyk, F. 1972. Morphological adaptations and population structures of the Danish Chalk brachiopods (Maastrichtian, Upper Cretaceous). Det Kongelige Danske Videnskabernes Selskab, Biologiske Skrifter 19: 1-57.

Taddei Ruggiero, E., and M.A. Bitner. 2008. Bioerosion on the brachiopod shell-a Cenozoic perspective. In Brachiopod Research into the Third Millenium, eds M. Cusack and D.A.T. Harper. Earth and Environmental Science Transactions of the Royal Society of Edinburgh 98: 369-378.

Thomson, J.A. 1926. A revision of the subfamilies of the Terebratulidae (Brachiopoda). The Annals and Magazine of Natural History (9)18:523-530.

Toulmin, L.D. 1940. Eocene brachiopods from the Salt Mountain limestone of Alabama. Journal of Paleontology 14: 227-233.

van Roy, A. 1980. Pliothyrina, genre terebratulide (Brachiopode) nouveau du Néogène. Bulletin Institut Royale Science Naturelle de Belgique 52: 1-9.

Venzo, S. 1941. Fossili oligocenici della Valle del Maso (Valsugana). Studi Trentini di Scienze Naturali 22: 1-25.

Vincent, G. 1886. Liste des coquilles du tongrien inférieur du Limbourg belge. Annales de la Société royale malacologique de Belgique 21: 4-16.

Vincent, E. 1893. Contribution à la paléontologie des terrains tertiaires de la Belgique. Annales de la Société Royale Zoologique de Belgique 28: 38-64.

Vincent, E. 1923. Quelques remarques sur des Brachiopodes tertiaires de Belgique et description d'une espèce nouvelle d'Argyrotheca. Annales de la Société Royale Zoologique de Belgique 53: 49-53. 
von Koenen, A. 1894. Das Norddeutsche Unter-Oligocän und seine Mollusken-Fauna. Abhandlungen zur geologischen Specialkarte von Preussen und den Thüringischen Staaten 10: 1250-1392.

Waagen, W.H. 1883. Salt Range fossils, vol. I, part 4. Productus Limestone fossils, Brachiopoda. Memoirs of Geological Survey of India, Palaeontologia Indica (series 13) 2: 391-546.

Waagen, W.H. 1885. Salt Range fossils, vol. I, part 4. Productus Limestone fossils, Brachiopoda. Memoirs of Geological Survey of India, Palaeontologia Indica (series 13) 5: 729-770.
Williams, A., S.J. Carlson, C.H.C. Brunton, L.E. Holmer, and L. Popov. 1996. A supra-ordinal classification of the Brachiopoda. Philosophical Transactions of the Royal Society of London. Series B 351: 1171-1193.

Zelinskaya, V.A. 1962. Brachiopods from the Upper Eocene of Ukraine. Paleontological Journal 2: 106-111. (in Russian).

Zelinskaya, V.A. 1975. Brachiopods from the Paleogene of the Ukraine, 148. Kiev: Naukova Dumka. (in Russian). 